\title{
Influence of bone loss and inclination of incisor on periradicular stresses due to simulated bite force
}

\author{
Influência da perda óssea e da inclinação do incisivo na distribuição de tensões perirradiculares \\ decorrentes da simulação de forças oclusais
}
Samuel RODRIGUES ${ }^{\mathrm{a}}$, José Roberto CORTELLI ${ }^{\mathrm{a}}$, Ana Paula Rosifini Alves CLARO ${ }^{\mathrm{b}}$, Rosana Villela CHAGAS ${ }^{a}$, Lais Regiane da Silva CONCÍLIO ${ }^{a}$, Luciana Paula Benicio ARCAS, Cristiane Aparecida de Assis CLARO ${ }^{\text {a* }}$

${ }^{a}$ UNITAU - Universidade de Taubaté, Taubaté, SP, Brasil

'UNESP - Universidade Estadual Paulista, Faculdade de Engenharia de Guaratinguetá, Guaratinguetá, SP, Brasil

\begin{abstract}
Resumo
Objetivo: Introdução: Adultos com sequelas de doenças periodontais tendem a apresentar perda óssea, com consequente vestibularização dos incisivos superiores. A influência da perda óssea e da inclinação do incisivo superior na distribuição de tensões devido a forças mastigatórias simuladas foram avaliadas nesse estudo. Material e método: Modelos em resina epóxi foram confeccionados em três condições (sem perda óssea e com perda óssea de $5 \mathrm{~mm}$ e $8 \mathrm{~mm}$ ). Aumentos na inclinação vestibular do incisivo superior de $10^{\circ}$ e $20^{\circ}$ foram obtidos com um bloco metálico chanfrado. Cargas de $100 \mathrm{~N}$ foram aplicadas cinco vezes em cada condição usando uma máquina de ensaio universal. Os modelos foram observados e filmados com um polariscópio circular. Ordens de franjas isocromáticas (tensões) nas faces vestibular, lingual e apical foram registradas. A concordância dos dados foi avaliada pelo teste kappa ponderado e os resultados foram 0,89 e 0,82 para intra e interexaminadores, respectivamente. Resultado: Os resultados dos testes de Kruskal-Wallis e SNK indicaram maiores tensões $(2,0)$ com aumento da inclinação vestibular na face vestibular; maiores tensões $(2,67)$ com aumento da perda óssea; maior tensão com a associação de perda óssea e inclinação vestibular $(3,6)$; e as maiores tensões tenderam a concentrar-se na face vestibular, exceto em casos de inclinação normal e sem perda óssea $(0,45)$. Conclusão: Concluiu-se que aumentos tanto da inclinação vestibular dos incisivos superiores quanto da perda óssea aumentam as tensões perirradiculares, e a combinação desses fatores aumenta ainda mais as tensões devido às forças mastigatórias, com a maior concentração na face vestibular.
\end{abstract}

Descritores: Migração dentária; força de mordida; análise de estresse dentário; reabsorção óssea.

\begin{abstract}
Objective: Introduction: Adults with sequelae of periodontal disease tend to have bone loss, with consequent flaring of the maxillary incisors. The influence of bone loss and the inclination of the maxillary incisor in the distribution of stresses due to simulated bite forces was studied. Material and method: Models in epoxy resin were made in three conditions (without bone loss and with bone loss of $5 \mathrm{~mm}$ and $8 \mathrm{~mm}$ ). Increases in the labial inclination of the maxillary incisor of $10^{\circ}$ and $20^{\circ}$ were obtained with a beveled metallic block. Loads of $100 \mathrm{~N}$ were applied five times in each condition using a universal test machine. The models were observed and filmed with a circular polariscope. Orders of isochromatic fringes (stresses) on the labial, lingual, and apex surfaces were recorded. The agreement of the data was evaluated using the weighted kappa test, and the results were 0.89 and 0.82 for intra- and inter-examiners, respectively. Result: The results of the Kruskal-Wallis and SNK tests indicated higher stresses (2.0) with increased labial inclination in the labial surface; higher stresses (2.67) with increased bone loss; higher greater stresses with the association of bone loss and labial-inclination (3.6); and the highest stresses tended to concentrate on the labial surfaces, except in cases of normal inclination and without bone loss (0.45). Conclusion: It was concluded that increases in both the labial inclination of the maxillary incisors and bone loss increase periradicular stresses, and the combination of these factors further increases the stresses due to bite forces, with the highest concentration on the labial side.
\end{abstract}

Descriptors: Tooth migration; bite force; dental stress analysis; bone resorption. 


\section{INTRODUCTION}

Periodontal disease results in inflammation of the supportive tissues of the teeth and progressive loss of connective tissue attachment. Periodontal disease largely affects adults and older people. Although most adults have some gingival inflammation, approximately $11 \%$ of the global adult population has severe progressive periodontal disease, which can ultimately lead to premature tooth loss ${ }^{1}$. Adults with sequelae of periodontal disease tend to have bone loss, with consequent flaring of the maxillary incisors. This change in the inclination of the incisors can be explained in part as a result of masticatory loads on the reduced periodontal support. Such a change may impact aesthetics and function and is one of the reasons for the demand for orthodontic treatment in adults. In addition to being carried out by a multidisciplinary team, the orthodontic treatment of adults also requires complex planning of biomechanics, as these cases usually have midline diastema or generalized spaces, especially in the anterior segment; labial flaring and overeruption of the maxillary incisors; rotation; migration and loss of teeth ${ }^{2,3}$.

It is essential that these patients be seen by a periodontist to identify and treat the periodontal disease prior to orthodontic treatment. It is important to maintain periodontal health during the orthodontic treatment so that the orthodontic movement occurs in the absence of periodontal disease and thus results in a good outcome. It is well known that orthodontics can promote the alignment of the teeth in order to facilitate buccal hygiene and the maintenance of periodontal health, improving the slopes of the teeth and the occlusion and thus distributing the masticatory loads more evenly. It has been reported that the resorption of alveolar bone can be prevented and that the multidisciplinary orthodontic treatment of periodontal patients with pathologic tooth migration is effective and helpful ${ }^{4}$.

When bone loss occurs, the center of resistance tends to move in the apical direction. In addition to the amount of bone, other factors that may influence the location of the center of resistance include the application direction of the force and the axial inclination of the tooth ${ }^{5}$.

The force application direction (orthodontic or masticatory), axial inclination of the incisors (well positioned, labial-inclined, or lingual-inclined), and the amount of surrounding bone (none, moderate bone loss, or excessive bone loss) can generate different stresses in the periodontium. Thus, the present study aims to establish a relationship between increased stresses and greater labial inclination of the incisors due to bone loss. This relationship is important to both justify orthodontic treatment in patients with sequelae of periodontal disease as well as to limit the proposed compensatory orthodontic treatment, as it provides a view of the variation of the magnitude of stresses around the incisors due to the simulation of occlusal loads. The alternative hypothesis tested in this study is that bone loss simulation and the inclination of the incisors influence the stress distribution in photoelastic models due to occlusal loading, and the combination of proclined incisors with little bone support results in greater magnitudes of stress in incisor periodontium.

\section{MATERIAL AND METHOD}

Three photoelastic models were built simulating no bone loss and bone loss of $5 \mathrm{~mm}$ and $8 \mathrm{~mm}$. Two steel devices were also built, one with $10^{\circ}$ inclination and the other with $20^{\circ}$, which allowed varying the inclination of the maxillary incisors (well positioned; flaring at $+10^{\circ}$ and $+20^{\circ}$ ).

For the construction of the photoelastic models, artificial teeth (B2-306/Kilgore-Nissin, Kilgore International Michigan, USA) were used, which were initially immersed in molten wax, simulating different bone level conditions. These wax models were molded with silicone. The wax was later removed, and then the epoxy resin was poured (GY 1109 BR e Aradur 830, Araldite ${ }^{\circledR}$, São Paulo, Brazil).

A load of $100 \mathrm{~N}$ was applied to the models, using a universal test machine (AG-X 50kN, Shimadzu, Tokyo, Japan) with a $5 \mathrm{kN}$ load cell. A pencil mark was made in the on the middle of the incisor lingual surface in order to consistently apply the force at the same point. A metal tip was made to simulate the occlusal contact area $(0.6 \mathrm{~mm} \times 1.2 \mathrm{~mm})^{6}$.

A circular polariscope (white light, light diffuser, polarizer, 1/4 wavelength plate, photoelastic model fixed on the basis of universal test machine, $1 / 4$ wavelength plate, analyzer, and video camera) in dark-field configuration (optical axes of polarizer and analyzer crossed to each other, and the axes of the $1 / 4$ wavelength plates also crossed each other at $45^{\circ}$ to the analyzer and polarizer) ${ }^{7}$ was used to visualize the periradicular stresses caused by the applied loads.

The models were observed in the polariscope before the application of forces to verify the absence of residual stresses in the material. Then, the models were subjected to the application of load by means of a universal test machine $(0.5 \mathrm{~mm} /$ minute) until $100 \mathrm{~N}$.

The recorded images were analyzed by assigning values to the isochromatic fringe orders in accordance with the color sequences produced in the circular polariscope with white light, in the dark field configuration (black $=0$; gray $=0.28$; white $=0.45$; yellow $=0.60$; orange $=0.79$; red $=0.9$; tin of passage $=1.0$; blue $=1.06$; blue-green $=1.2$; green-yellow $=1.38$; orange $=1.62$; red $=1.81$; tin of passage $2=2.0$; green $=2.33$; green -yellow $=2.5$; pink $=2.67$; tin of passage $3=3.0$; green $=3.1$; pink $=3.6$; tin of passage $4=4.0$; green $=4.13)^{7}$ in periradicular area (labial, lingual, and apical) and recorded on sheets according to the level of bone loss and inclination of the incisors. The values of fringe orders were submitted to statistical analysis.

A significance level of 5\% was adopted for all statistical tests. To check the reliability of the data and calibrate the analysis, two observers checked the images in intervals of one week, aiming to find any intra- and inter-observer errors by applying a weighted kappa test. The Kruskal-Wallis test was used to compare the stresses among the groups with different bone levels, to compare the stresses among the groups with different incisor inclinations, and to compare all groups to verify whether the combination of excessive bone loss and incisor labial inclination increases the stress concentration. 


\section{RESULT}

Figure 1 illustrates an example of five images analyzed from each one of the nine groups. A qualitative analysis indicates that the magnitudes of the stresses (isochromatic fringes) tend to increase with increased bone loss and also with the increase of the labial inclination of the upper incisor.

The reliability of the data (reproducibility intra- and inter-observer) was confirmed by the weighted kappa test, and the results showed an almost perfect agreement, given that the kappa coefficients were 0.89 for intra-observer (95\% confidence interval, 0.86-0.92) and 0.82 for inter-observer ( $95 \%$ confidence interval, $0.77-0.87$ ) analysis.

Table 1 shows the results of the Kruskal-Wallis test comparing the stresses on the labial, lingual, and apex surfaces, varying the conditions of bone loss. The stress on the labial side was higher in the group with increased bone loss $(\mathrm{p}=0.001)$. In Table 2 , when comparing the stresses between groups with different degrees of inclination of the maxillary incisors, the results of the Kruskal-Wallis test showed statistically significant differences between groups $(\mathrm{p}=0.002)$. The highest stresses occurred in the group with more pronounced flaring $\left(+20^{\circ}\right)$ on the labial surface.

Table 3 shows the results of the Kruskal-Wallis comparing the stresses, considering the surfaces (labial, lingual, and apex) and varying the degree of labial inclination of the maxillary incisors
Table 1. Results of Kruskal-Wallis test for comparison among the isochromatic fringe orders (stress) in different bone loss conditions (none, $5 \mathrm{~mm}$, and $8 \mathrm{~mm}$ of bone loss) under a simulated bite force of $100 \mathrm{~N}$

\begin{tabular}{cccc}
\hline Conditions & $\begin{array}{c}\text { Labial } \\
\text { Median }\end{array}$ & $\begin{array}{c}\text { Lingual } \\
\text { Median }\end{array}$ & $\begin{array}{c}\text { Apex } \\
\text { Median }\end{array}$ \\
\hline No bone loss & $0.45^{\mathrm{C}}$ & $0.9^{\mathrm{B}}$ & $0.9^{\mathrm{C}}$ \\
\hline Bone loss of $5 \mathrm{~mm}$ & $1.38^{\mathrm{B}}$ & $1.06^{\mathrm{A}}$ & $1.2^{\mathrm{B}}$ \\
\hline Bone loss of $8 \mathrm{~mm}$ & $2.67^{\mathrm{A}}$ & $0.6^{\mathrm{C}}$ & $1.38^{\mathrm{A}}$ \\
\hline
\end{tabular}

Labial: $\mathrm{H}=13.20$ and $\mathrm{p}=0.001$. Lingual: $\mathrm{H}=14.00$ and $\mathrm{p}<0.001$. Apex: $\mathrm{H}=14.00$ and $\mathrm{p}<0.001$. Capital letters differ in the vertical direction.

Table 2. Results of Kruskal-Wallis test for comparison among the isochromatic fringe orders (stress) in different incisor inclination conditions (normal, increase of $+10^{\circ}$ and $+20^{\circ}$ ) under a simulated bite force of $100 \mathrm{~N}$

\begin{tabular}{|c|c|c|c|}
\hline Regions & Labial & Lingual & Apex \\
\hline Incisor inclination & Median & Median & Median \\
\hline Normal & $0.45^{\mathrm{C}}$ & $0.9^{\mathrm{A}}$ & $0.9^{\mathrm{A}}$ \\
\hline Increase of $+10^{\circ}$ & $1.62^{\mathrm{B}}$ & $0.79^{\mathrm{B}}$ & $0.6^{\mathrm{B}}$ \\
\hline Increase of $+20^{\circ}$ & $2.0^{\mathrm{A}}$ & $0.28^{\mathrm{C}}$ & $0.45^{\mathrm{C}}$ \\
\hline
\end{tabular}

Labial: $\mathrm{H}=12.96$ and $\mathrm{p}=0.002$. Lingual: $\mathrm{H}=12.86$ and $\mathrm{p}=0.002$. Apex: $\mathrm{H}=14.00$ and $\mathrm{p}<0.001$. Capital letters differ in the vertical direction.

\section{No bone loss \\ Normal inclination of maxillary incisor \\ Bone loss of $5 \mathrm{~mm} \quad$ Bone loss of $8 \mathrm{~mm}$}
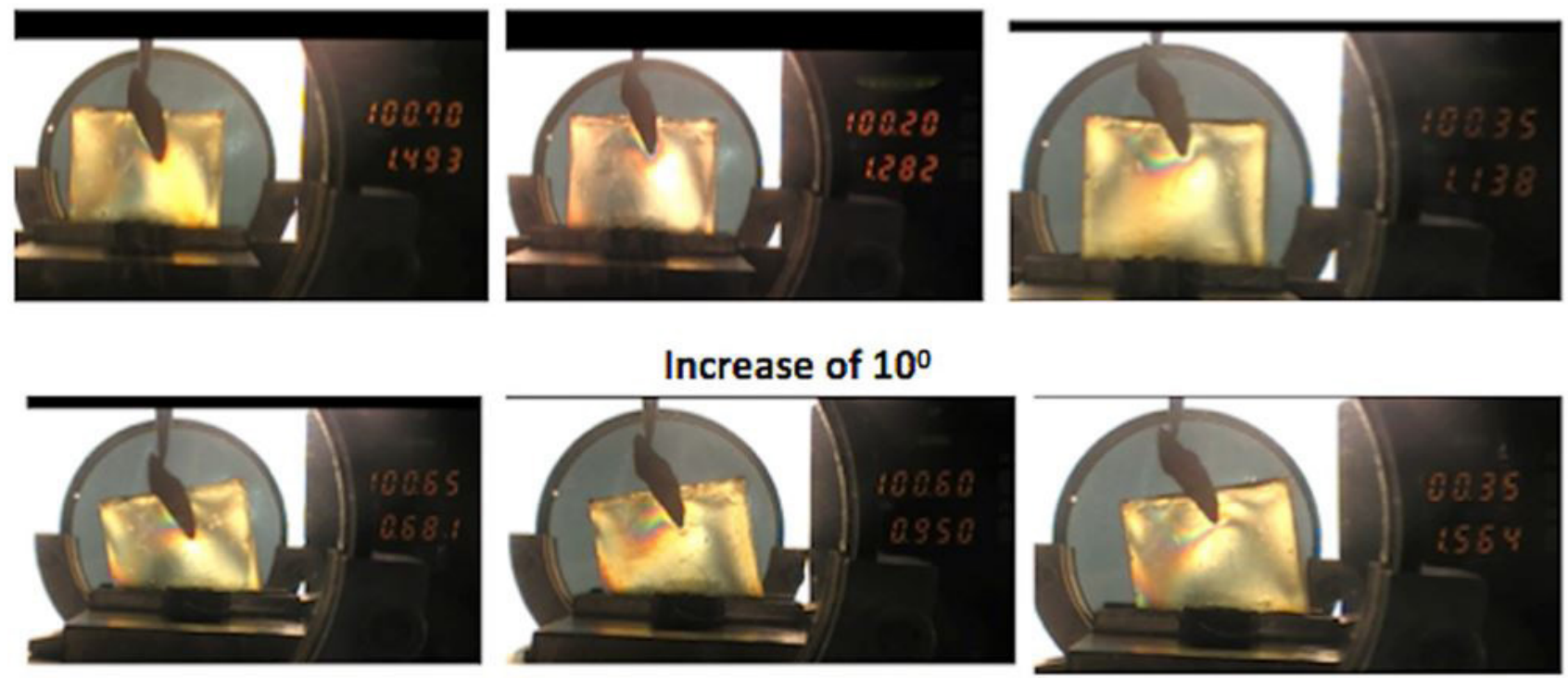

Increase of $20^{\circ}$
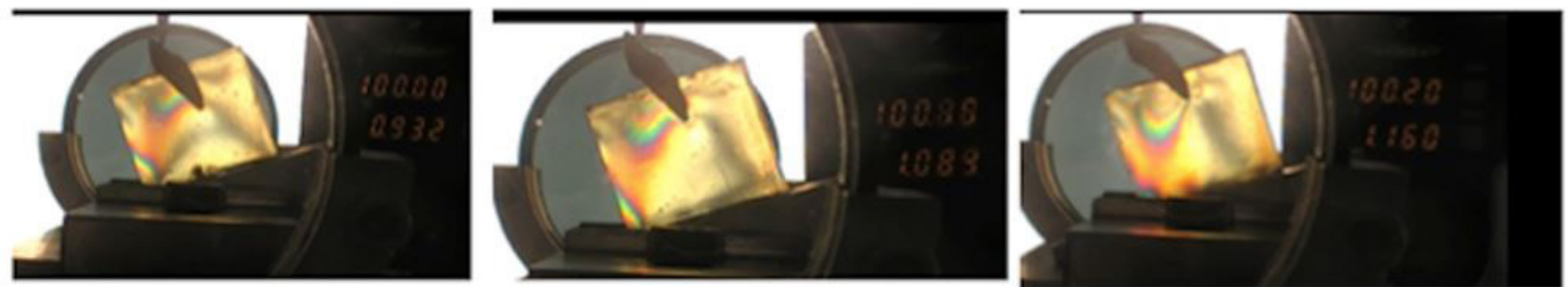

Figure 1. Example of the images analyzed for each of the groups. 
(normal, $+10^{\circ}$, and $+20^{\circ}$ ) and bone loss (no bone loss, bone loss of $5 \mathrm{~mm}$, and bone loss of $8 \mathrm{~mm})$. The greatest stress on the labial surface (3.6) occurred with the combination of $8 \mathrm{~mm}$ bone loss and an increase of $+20^{\circ}$ of the incisor labial inclination. The lowest stress (0.45) occurred with the combination of normal tilt and absence of bone loss. Such combination allowed the distribution of stresses to occur relatively evenly on the three sides analyzed.

Figure 2a shows a significant interaction $(\mathrm{p}<0,001)$ among the factors, bone loss, flaring of the incisors, and the periradicular regions. The effect of the interaction between bone loss and flaring

Table 3. Results of Kruskal-Wallis test for comparison among the isochromatic fringe orders (stress) in the labial, lingual, and apex areas in all test conditions under a simulated bite force of $100 \mathrm{~N}$

\begin{tabular}{|c|c|c|c|}
\hline & Labial & Lingual & Apex \\
\hline & Median & Median & Median \\
\hline Normal inclination and No bone loss & $0.45^{\mathrm{Gb}}$ & $0.9^{\mathrm{Ba}}$ & $0.9^{\mathrm{Ca}}$ \\
\hline Normal inclination and Bone loss of $5 \mathrm{~mm}$ & $1.38^{\mathrm{Fa}}$ & $1.06^{\mathrm{Ab}}$ & $1.2^{\mathrm{Ba}}$ \\
\hline Normal inclination and Bone loss of $8 \mathrm{~mm}$ & $2.67^{\mathrm{Ca}}$ & $0.6^{\mathrm{Cc}}$ & $1.38^{\mathrm{Ab}}$ \\
\hline Increase of $+10^{\circ}$ and No bone loss & $1.62^{\mathrm{Ea}}$ & $0.79^{\mathrm{Bb}}$ & $0.6^{\mathrm{Ec}}$ \\
\hline Increase of $+10^{\circ}$ and Bone loss of $5 \mathrm{~mm}$ & $2.0^{\mathrm{Da}}$ & $0.6^{\mathrm{Cc}}$ & $0.79^{\mathrm{Db}}$ \\
\hline Increase of $+10^{\circ}$ and Bone loss of $8 \mathrm{~mm}$ & $3.0^{\mathrm{Ba}}$ & $0.9^{\mathrm{Bb}}$ & $0.9^{\mathrm{Cb}}$ \\
\hline Increase of $+20^{\circ}$ and No bone loss & $2.0^{\mathrm{Da}}$ & $0.28^{\mathrm{Dc}}$ & $0.45^{\mathrm{Fb}}$ \\
\hline Increase of $+20^{\circ}$ and Bone loss of $5 \mathrm{~mm}$ & $2.67^{\mathrm{Ca}}$ & $0.9^{\mathrm{Bb}}$ & $0.9^{\mathrm{Cb}}$ \\
\hline Increase of $+20^{\circ}$ and Bone loss of $8 \mathrm{~mm}$ & $3.6^{\mathrm{Aa}}$ & $0.28^{\mathrm{Dc}}$ & $1.0^{\mathrm{Bb}}$ \\
\hline
\end{tabular}

Labial: $\mathrm{H}=43.63$ and $\mathrm{p}<0.001$. Lingual: $\mathrm{H}=43.50$ and $\mathrm{p}<0.001$. Apex: $\mathrm{H}=43.15$ and $\mathrm{p}<0.001$. Capital letters differ in the vertical direction. Lower-case letters differ in the horizontal direction.

Figure 2a

Interaction plot - Data means for fringe Order

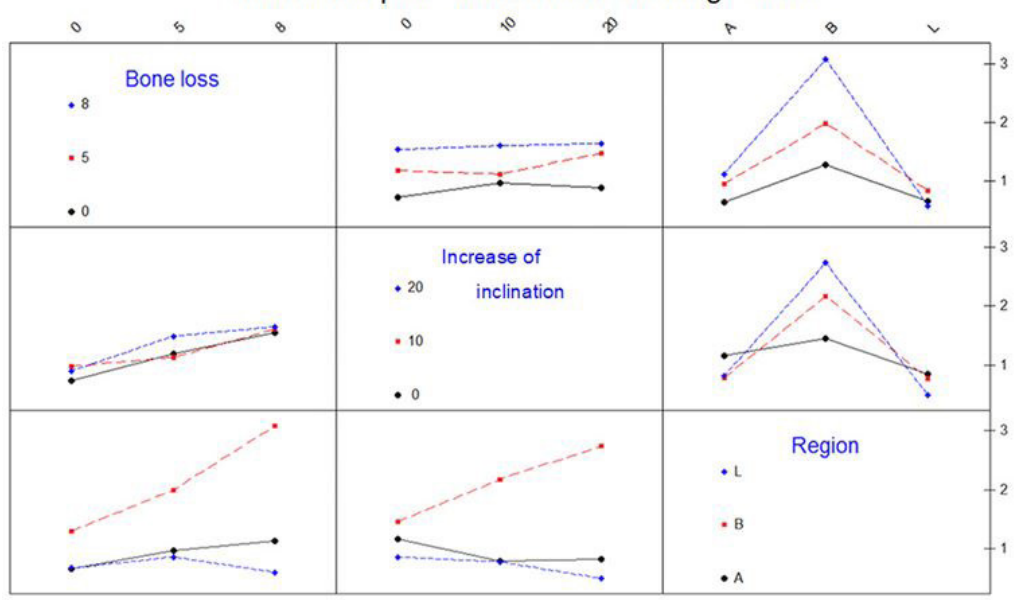

Figure $2 b$

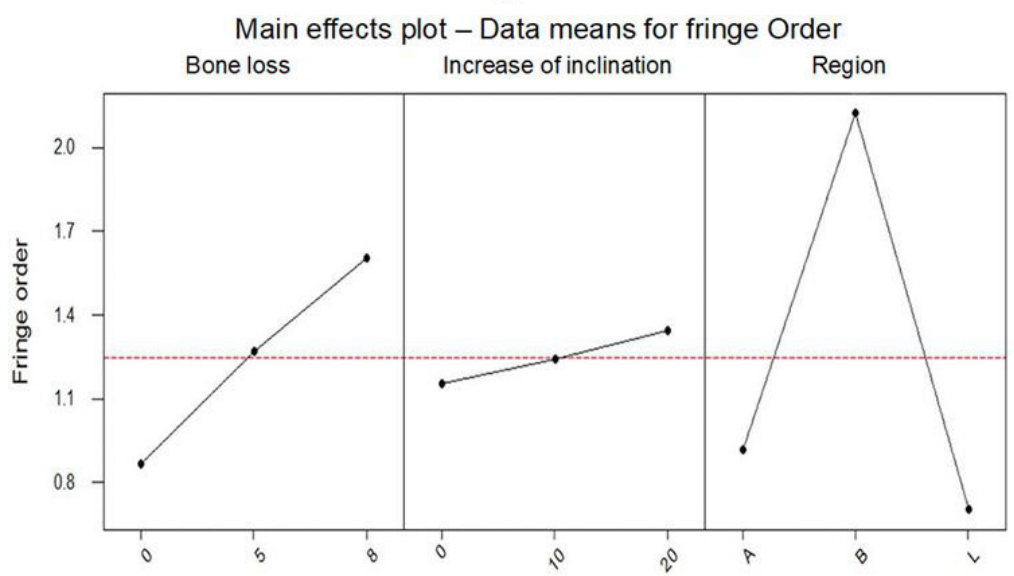

Figure 2. (a) Graph of the interaction among the factories, bone loss, flaring of the incisors, and the periradicular regions. (b) Graph of the main effect, data means for fringe order. 
of the incisors depends on what region is analyzed. The distribution of the stresses among the periradicular regions was much better in the photoelastic models without bone loss and normal inclination of the incisors than in the cases with extreme bone loss and flaring of the incisors. In these cases, the stresses increased in the labial region and decreased in the lingual region. In Figure 2b, it is possible to see that the fringe orders increase with bone loss of $8 \mathrm{~mm}$ and additional flaring of $20^{\circ}$, and it is also the greatest in the bucal region.

\section{DISCUSSION}

The photoelasticity method was chosen as an experimental method because it has already been validated in dentistry through histological studies ${ }^{8,9}$ for periradicular stress analysis. The use of the circular polariscope allowed the isochromatic fringes to be seen, showing the magnitude of the stresses. Due to the dark-field configuration of the polariscope, the periradicular regions that were not stressed are black (see picture 1). This is because the photoelastic resin is optically isotropic when free of stress, but in the regions where there are stresses the resin become temporarily optically anisotropic (birefringence). The use of white light allowed a sequence of colors of isochromatic fringes to be seen. The magnitude of the force $(100 \mathrm{~N})$ used to simulate the masticatory load in the region of the anterior teeth was defined based on the literature ${ }^{10-12}$.

Bone loss influenced the magnitude of the stresses, given that there was a higher amount of isochromatic fringes in models simulating bone loss, especially those with a simulated bone loss of $8 \mathrm{~mm}$ (Table 1). These results are in agreement with those found in the literature ${ }^{13}$, which also identified increased stresses related to bone loss simulation; however, the previous study simulated the application of orthodontic forces $(1 \mathrm{~N})$ in the incisors and used the finite element method, whereas the present study simulated masticatory loads $(100 \mathrm{~N})$ and utilized photoelasticity.

The simulation of bone loss also changed the pattern of distribution of the stresses around the root. It can be observed that with $8 \mathrm{~mm}$ of bone loss the stresses were highest, and they also differed among the periradicular areas: labial (2.67), lingual (0.6), and apex (1.38). In the absence of bone loss the stresses were the lowest and distributed more uniformly (labial $=0.45$, lingual $=0.9$, and apex $=0.9$ ), and on the labial surface, where the bone is usually thinner, the magnitude of the stress was significantly lower, which is a very favorable situation for maintaining bone tissue (Table 3 ).

The differences in the magnitudes and distribution of stresses occurring in this study could be explained by two assertions: the increase of alveolar bone loss decreases the distance between the center of resistance and the center of the rotation of the tooth ${ }^{13}$, and the incisors with a high degree of inclination experience more compressive stress concentrated at the apices than incisors that are more upright ${ }^{14}$.

The results of this study demonstrate that labial inclinations promote increased stresses on the labial face (normal inclination $=0.45$; flaring $+10^{\circ}=1.62$; flaring $\left.+20^{\circ}=2.0\right)($ Table 2$)$, and these tend to be more focused in the labial region (2.0) than in the lingual (0.28) and apex (0.45) regions (Table 3 ). This result is relevant because the increase of stresses may induce bone resorption on the labial surface and increase the bone loss in this region. At this point it is important to remember that the anterior maxillary region is predominantly bone resorption during craniofacial growth.
In addition to the flaring of the maxillary incisors due to periodontal disease, one should consider the case of class III malocclusion, in which the maxillary incisors are often already proclined due to natural compensation mechanisms or orthodontic dental movement ${ }^{15}$. In such cases, the occlusal force passes far ahead of the center of resistance, resulting in a substantial moment for flaring of the incisors, and the moment increases as the incisors are more proclined ${ }^{16}$. This is consistent with the results of the present study because the stress increased when the flaring of the maxillary incisors increased (Table 2).

Skeletal class III patients may be more vulnerable to alveolar bone loss during orthodontic treatment. Therefore, it is important to take special care to avoid aggravating preexisting alveolar bone loss in the anterior teeth ${ }^{17}$.

Considering the results of the present study, which show a significant increase in the stress on the labial surface with increasing incisor angulation, and as a change of $20^{\circ}$ in upper incisor angulation will alter the overjet by an average of $1.96 \mathrm{~mm}^{18}$, the compensatory treatment of class III malocclusions should be carefully planned. These cases should be monitored during post-orthodontic treatment to observe whether the thickness of the bone has been preserved and to control the distribution of the masticatory forces to avoid excessive loads and consequent stress concentration in the bone.

The combination of two factors, bone loss and the flaring of the maxillary incisors, potentiates the increase of the stress around the root. The highest concentration of stress was observed in the photoelastic model, where a bone loss of $8 \mathrm{~mm}$ and angulation of $20^{\circ}$ was simulated (Table 3). This result reinforces the need to correct the excessive angulation of the incisors, maintain adequate inclination, and receive periodontal treatment to preserve the bone level.

The increase in alveolar bone loss and labial tooth inclination resulted in an increase in stresses. It is known that such stresses might cause root resorption at the root apex, despite the application of controlled tipping to the incisors ${ }^{19}$.

It is hoped that the present in vitro study encourages future clinical trials to investigate the relationship between the bone loss and angulation of the incisors with bone and root reabsorption.

\section{CONCLUSION}

1) Stresses tend to concentrate more on the labial surface of the incisors, especially in cases of bone loss and increased labial inclination.

2) The presence of bone loss implies a significant increase of periradicular stresses under occlusal forces.

3) The presence of exaggerated labial incisors caused increased stresses periradicular under occlusal forces.

4) The combination of bone loss and flaring of the maxillary incisors significantly expands the increased stresses periradicular under occlusal forces.

\section{ACKNOWLEDGEMENTS}

The authors thank the Conselho Nacional de Desenvolvimento Científico e Tecnológico - CNPq for the financial support (PIBIC: CNPq No 137084/2012-9). 


\section{REFERENCES}

1. Marcenes W, Kassebaum NJ, Bernabé E, Flaxman A, Naghavi M, Lopez A, et al. Global burden of oral conditions in 1990-2010: a systematic analysis. J Dent Res. 2013 Jul;92(7):592-7. http://dx.doi.org/10.1177/0022034513490168. PMid:23720570.

2. Gkantidis N, Christou P, Topouzelis N. The orthodontic-periodontic interrelationship in integrated treatment challenges: a systematic review. J Oral Rehabil. 2010 May;37(5):377-90. http://dx.doi.org/10.1111/j.1365-2842.2010.02068.x. PMid:20202098.

3. Calheiros A, Fernandes A, Quintão CA, Souza EV. Movimentação ortodôntica em dentes com comprometimento periodontal: relato de um caso clínico. Rev Dent Press Ortodon Ortop Facial. 2005;10(2):111-8. http://dx.doi.org/10.1590/S1415-54192005000200014.

4. Xie Y, Zhao Q, Tan Z, Yang S. Orthodontic treatment in a periodontal patient with pathologic migration of anterior teeth. Am J Orthod Dentofacial Orthop. 2014 May;145(5):685-93. http://dx.doi.org/10.1016/j.ajodo.2013.08.018. PMid:24785933.

5. Papageorgiou IS. The center of resistance of teeth in orthodontics. Hellenic Orthodontic Review. 2005;8(1):43-57.

6. Poiate IA, Vasconcellos AB, Mori M, Poiate E Jr. 2D and 3D finite element analysis of central incisor generated by computerized tomography. Comput Methods Programs Biomed. 2011 Nov;104(2):292-9. http://dx.doi.org/10.1016/j.cmpb.2011.03.017. PMid:21531473.

7. American Society for Testing and Materials - ASTM. D4093-95: standard test method for photoelastic measurements of birefringence and residual strains in transparent or translucent plastic materials. West Conshohocken: ASTM; 2001.

8. Glickman I, Roeber FW, Brion M, Pameijer JH. Photoelastic analysis for internal stresses in the periodontium created by occlusal forces. J Periodontol. 1970 Jan;41(1):30-5. http://dx.doi.org/10.1902/jop.1970.41.1.30. PMid:4906551.

9. Brodsky JF, Caputo AA, Furstman LL. Root tipping: a photoelastic-histopathologic correlation. Am J Orthod. 1975 Jan;67(1):1-10. http:// dx.doi.org/10.1016/0002-9416(75)90124-4. PMid:803022.

10. Rosa LB, Semprini M, Siéssere S, Hallak JE, Pagnano VO, Regalo SC. Correlation between bite force and electromyographic activity in dentate and partially edentulous individuals. Electromyogr Clin Neurophysiol. 2009 Sep-Oct;49(6-7):291-7. PMid:19845101.

11. Pesqueira AA, Goiato MC, Santos DM, Haddad MF, Andreotti AM, Moreno A. Stress analysis in oral obturator prostheses: imaging photoelastic. J Biomed Opt. 2013 Jun;18(6):061203. http://dx.doi.org/10.1117/1.JBO.18.6.061203. PMid:23143194.

12. Eser A, Tonuk E, Akca K, Dard MM, Cehreli MC. Predicting bone remodeling around tissue- and bone-level dental implants used in reduced bone width. J Biomech. 2013 Sep;46(13):2250-7. http://dx.doi.org/10.1016/j.jbiomech.2013.06.025. PMid:23876712.

13. Geramy A. Alveolar bone resorption and the center of resistance modification (3-D analysis by means of the finite element method). Am J Orthod Dentofacial Orthop. 2000 Apr;117(4):399-405. http://dx.doi.org/10.1016/S0889-5406(00)70159-4. PMid:10756265.

14. Kanjanaouthai A, Mahatumarat K, Techalertpaisarn P, Versluis A. Effect of the inclination of a maxillary central incisor on periodontal stress: Finite element analysis. Angle Orthod. 2012 Sep;82(5):812-9. http://dx.doi.org/10.2319/100611-627.1. PMid:22360298.

15. Troy BA, Shanker S, Fields HW, Vig K, Johnston W. Comparison of incisor inclination in patients with Class III malocclusion treated with orthognathic surgery or orthodontic camouflage. Am J Orthod Dentofacial Orthop. 2009 Feb;135(2):146-7. http://dx.doi.org/10.1016/j. ajodo.2008.10.004. PMid:19201319.

16. Kim SJ, Kim KH, Yu HS, Baik HS. Dentoalveolar compensation according to skeletal discrepancy and overjet in skeletal Class III patients. Am J Orthod Dentofacial Orthop. 2014 Mar;145(3):317-24. http://dx.doi.org/10.1016/j.ajodo.2013.11.014. PMid:24582023.

17. Kook YA, Kim G, Kim Y. Comparison of alveolar bone loss around incisors in normal occlusion samples and surgical skeletal Class III patients. Angle Orthod. 2012 Jul;82(4):645-52. http://dx.doi.org/10.2319/070111-424.1. PMid:22129151.

18. Sangcharearn Y, Ho C. Effect of incisor angulation on overjet and overbite in Class II camouflage treatment. Angle Orthod. 2007 Nov;77(6):10118. http://dx.doi.org/10.2319/111206-460.1. PMid:18004929.

19. Choi SH, Kim YH, Lee KJ, Hwang CJ. Effect of labiolingual inclination of a maxillary central incisor and surrounding alveolar bone loss on periodontal stress: a finite element analysis. Korean J Orthod. 2016 May;46(3):155-62. http://dx.doi.org/10.4041/kjod.2016.46.3.155. PMid:27226961.

\section{CONFLICTS OF INTERESTS}

The authors declare no conflicts of interest.

\section{${ }^{\star}$ CORRESPONDING AUTHOR}

Cristiane Aparecida de Assis Claro, UNITAU - Universidade de Taubaté, Faculdade de Odontologia, Departamento de Ortodontia, Rua Expedicionário Ernesto Pereira, 110, 12020-330, Taubaté - SP, Brasil, e-mail: cristiane.claro@unitau.com.br 